DOI: $10.17803 / 2313-5395 \cdot 2021 \cdot 3 \cdot 17 \cdot 507-516$

\title{
Overview of the 2nd International Congress on Civil Comparative Studies
}

\author{
Elena A. Morgunova \\ Kutafin Moscow State Law University (MSAL), Moscow, Russia
}

Acknowledgements: This paper was prepared with the assistance of Amirkhan R. Meretukov who kindly contributed to the translation of the overview.

Cite as: Morgunova, E.A., (2021). Overview of the 2nd International Congress on Civil Comparative Studies. Kutafin Law Review, 8(3), pp. 507-516, doi: 10.17803/2313-5395.2021.3.17.507-516.

On December 4-5, 2020, Kutafin Moscow State Law University (MSAL) held the 2nd International Congress on Civil Comparative Studies "The Role of Human in Modern Civil Law" (Mozolinskie Readings), dedicated to the 9oth anniversary of the Kutafin Moscow State Law University. The congress was organized by the MSAL Department of Civil Law, the Scientific and Educational center "Private Law," "Statut" Publishing House, the Russian Arbitration Center of the Russian Institute of Modern Arbitration, the Institute of International Relations and Social and Political Sciences of Maurice Thorez Moscow State Linguistic University.

The Congress was organized with the participation of the MSAL Department of Civil and Administrative Court Proceedings and the Department of State History and Law.

Russian and foreign scholars from Austria, Armenia, the Republic of Belarus, Italy, China, Latvia, Poland and the United States, as well as a representative of the World Intellectual Property Organization attended the Congress. The number of participants of the congress totaled to over 600 people.

On the first day of the Congress, a plenary session and panel discussion "The Role of Human and the Role of IT in Judicial Protection" 
took place. Professor Elena E. Bogdanova, Dr. Sci. (Law), Acting Head of the Department of Civil Law, Kutafin Moscow State Law University (MSAL) and Vadim E. Mantrov, Dr. Sci. (Law), Associate Professor of the Faculty of Law, University of Latvia moderated the Congress plenary session.

William Elliott Butler, Honorary President of the Congress, Doctor of Law, John Edward Fowler Distinguished Professor of Law of the Pennsylvania State University Dickinson School of Law opened the Congress. Expressing his warmest wishes to the University, he noted the importance of holding the Congress dedicated to the memory of the outstanding civil jurist Viktor Pavlovich Mozolin timed to an important historical event, the 9oth anniversary of the MSAL.

The MSAL Vice-Rector for Science, Dr. Sci. (Law), Professor Vladimir N. Sinyukov addressed his welcoming words to the participants of the Congress. He noted that the topic of the Congress is of the highest interest, since a person always discovers new aspects in his nature. The development of natural sciences, biotechnology, and information technology puts the law to new branches of development, civil law being of great importance since it directly concerns a person. Vladimir Sinyukov drew attention to the event formats development within the framework of the Congress compared to last year mentioning that starting next year the event will acquire an interdepartmental character. The ViceRector informed all the participants of the Congress that this year at the University the Ministry of Education and Science has established the Federal Interdepartmental Center for Law and Biotechnology as a center in the field of genetic research and genetic technologies and invited Russian and foreign scholars to cooperate within the framework of the interdepartmental center.

After that, a guest from Erevan State University, namely, the Acting Head of the Department of Civil Law (Erevan State University), Ph. D., Associate Professor Tatevik Davtyan welcomed the participants. Ms. Davtyan thanked the organizers of the Congress for bringing the participants together for an important and timely congress. She noted that according to the analytical results, due to the technological revolution the speed of technological development, the development of artificial intelligence and big data is 10 times higher than the technical 
development of the industrial revolution and three thousand times larger than the industrial revolution. Legislators, lawyers, judges are facing the task of adapting legal regulation to the development of technologies. Ms. Davtyan noted that it is impossible for individual states to solve these large-scale problems; it is international cooperation that is essential to resolve these global issues.

Then the floor was given to the Head of Private Law Center of Kutafin Moscow State Law University, Dr. Sci. (Law), Professor, Deputy Chairman of the Organizing Committee Dmitry E. Bogdanov. He drew attention to the change in the vector of the research paradigm and mentioned that the attention in research addressing the person is increasing, and, therefore, the choice of the topic of the Congress is symptomatic. The Professor addressed a number of phenomena that have arisen as a result of the development of technology: the phenomenon of human vulnerability, the phenomenon of cyberspace, the transformation of the right to a personal image into the right to a digital image of a person, the phenomenon of an afterlife in the cloud (protection of personal non-property human rights), the phenomenon of robotization, evolution of civil liability.

The chairperson of the Organizing Committee of the Congress, Acting Head of the Department of Civil Law, Professor, Dr. Sci. (Law) Elena E. Bogdanova welcoming the participants of the Congress drew attention to the obvious underestimation of the role and place of a person in civil law, which became the reason that more and more people from a subject of law began to turn into an object of law, which is clearly manifested in the problems of surrogacy. Elena Bogdanova expressed her hope that, within the framework of the Congress, the participants will be able to share ideas on the problems of the role of a person in civil law.

The work of the Plenary Session of the Congress followed the welcoming speeches.

Professor William Elliott Butler, Honorary President of the Congress was the first to report. His speech was devoted to the consideration of such issues as artificial intelligence, civil law and international maritime law. The professor drew attention to the fact that artificial intelligence has penetrated the territory of international maritime law 
and civil law. Artificial intelligence is no longer a theoretical invention, but is becoming a reality with the further development of unmanned surface vehicles (USVs) or autonomous surface vessels (ASVs), as well as autonomous underwater vehicles (AUVs), sometimes called submersibles. International maritime law has faced the problem of how to consider the mentioned technological innovations in the context of the existing legal norms. The Distinguished Professor noted that international maritime law was conceived as a human-made and human-controlled law. According to the civil law concept, behind each vessel are its owner (natural or legal person) and a registration system that allows us to identify these persons, regardless of the level of trust or other forms of indirect ownership. However, artificial intelligence is challenging the foundations of the traditional system. Human participation, as civil and international maritime law understands it, is excluded from or kept to a minimum in the operating principle of robots equipped with artificial intelligence and capable of acting autonomously in the development, production, launch and handling of ships. Based on the assumption that the ship with artificial intelligence itself becomes a "being" or an "object", separated from any developer or manufacturer, after registration does it acquire the "legal personality" of the state whose flag it flies, or is it its own legal personality? The professor also raised the question of whether it is possible to prosecute a ship with artificial intelligence, when it is involved in smuggling, drug trafficking, piracy, ocean pollution or other actions for which criminal liability is enforced. Does it have a sufficient level of legal awareness and freedom to make decisions without remote indication or a direct order from a person or a corporate body created by a person? The professor drew attention to another concept that deserves consideration, namely, whether we can consider an artificially intelligent ship a "subject" of international law, at least in terms of compliance with treaties and the principles of customary international law. In conclusion, Professor W.E. Butler noted that civil law experts and international lawyers have faced the task of revising the relevant legal principles in order to adapt them to the new challenges associated with the use of artificial intelligence in the context of international maritime law. 
The next speaker was Christian Aschauer, Professor of Law at the Karl and Franz University of Graz (Austria), attorney, independent arbitrator. The topic of his speech was "Automated Decision Making in the Field of International Commercial Arbitration: Challenges and Risks."

The professor drew attention to the fact that artificial intelligence can be used to predict the outcome of a trial. This technology is called "predictable justice." Insurance companies developed it. As Professor K. Aschauer noted, in many jurisdictions, the law requires that arbitrators have characteristics that can only be inherent in humans. In doing so, human arbiters can, however, rely to a very limited extent on AI as an "electronic assistant," if its actions are transparent to the parties. An "electronic assistant" can perform the same limited tasks as an administrative secretary of an arbitration court. The professor noted that while computers are not allowed to act as arbitrators at this time, this might change in the future. Therefore, he proposed to consider the risks that may arise when computers make decisions in international arbitration. Among these risks, the professor first identified the risk of hidden AI biases. For example, he noted that AI feedback systems tend to reinforce the bias that is rooted in the original data. These algorithms cannot "unlearn" biases if their algorithms are not corrected. However, algorithms cannot be fixed because they are not transparent. This is called the black box problem. As the second problem in making the AI decision, the professor identified the lack of information about the facts, which the arbitration court found to be true; lack of assessment of the evidence presented by the parties; lack of discussion of legal norms; there is no summary of the parties' comments; lack of final legal assessment. Professor K. Aschauer drew the attention of the Congress participants to the fact that if we work with AI, then the reasons underlying the decision (or forecast) can only be found in how the algorithm is developed and in the data that was used to train the algorithm. The exact reasons for the decision remain unknown. It is necessary to consider what this might mean for society in which the obligation to provide a clear basis for legal decisions is an important part of the Rule of Law principle. The professor also drew attention to the problems of applying the principle of "the court 
knows the laws." Based on the discussion of the principle of "the court knows the laws," we must consider whether the algorithm should be allowed to go beyond the pleadings of the parties. Another important issue is the problem of accounting for fair factors that a person can take into account. Perhaps when AI makes a decision, these factors will simply disappear. In conclusion, Professor K. Aschauer noted that predominantly international arbitration should remain human.

Then the floor was given to the professor of the Federico II University of Naples, Doctor of Law, Carlo Amatucci. The topic of his speech was "The Enterprise as a Creative Organization in French Law: Defending Corporate Interests in the Light of Social Impact and Environmental Impact." In his speech, the professor spoke about the French law on corporations, adopted in May 2019, indicating that the adoption of this law is associated with a significant reform of the European law on corporations. The professor dwelled upon the concept of a corporation and an enterprise, noted the differences between them, and revealed the essence of legislative reform. Thus, he said that corporations should have a deeper meaning than the interests of the members of the corporation should. He also noted that when making decisions corporations must take into account the social and environmental consequences of their activities. This approach has emerged because the new generation sees injustice in the existing world and is looking for a new meaning in life.

Next, the floor was given to Ms. Ksenia Gygax, the WIPO Policy Officer on Artificial Intelligence and Data. She dwelled on the concept of artificial intelligence in a narrow and broad sense. The speaker drew attention to the fact that AI in the narrow sense is the solution of certain tasks that a person delegates to programs to solve certain tasks; in a broad sense, it is the performance of all or almost all human functions. However, now, as Ms. Gygax emphasized, WIPO understands $\mathrm{AI}$ in a narrow sense and within the WIPO framework, the issue of AI impact on intellectual property is being considered. With this purpose in mind, WIPO has prepared a document titled "Discussion on Artificial Intelligence and Intellectual Property" and presented it for widespread public discussion to fully consider the impact of artificial intelligence on intellectual property and to formulate the issues to be resolved at national levels. 
Professor Evgeny V. Bogdanov, Dr. Sci. (Law), Professor of the Department of Civil Law Disciplines of Plekhanov Russian University of Economics made a report on the problems of protecting personal non-property human rights in the digital age. During his speech, Professor Bogdanov noted that if in the past civil law experts tried to humanize a legal entity, now they are trying to humanize artificial intelligence. The professor stressed that artificial intelligence is not just an increased danger, but also a super-dangerous one and, therefore, special rules on liability for their causing harm should be applied to relations with its use, and not just the provisions of the Civil Code on liability for the injury inflicted by the activity with increased hazard. All those involved in the creation and exploitation of the artificial intelligence that led to harmful consequences provoked by its actions should be held accountable: developers, manufacturers, customizers, and operators. Moreover, they must have joint and several liability. This approach will discipline them, make them think more before launching artificial intelligence technologies into production, thus maximizing the protection of a person. Evgeniy Bogdanov noted that it is necessary to change the paradigm of civil law regulation of public relations. Is is necessary to consider personal non-property relations first, and only then property relations. Currently, there is civil law materialism, the matter is in the first place, and the person is in the second. The Distinguished Professor emphasized that digitalization is important, but it is necessary to minimize losses from their implementation. We need to fight not with digitalization, but with its consequences.

The floor was then given to Salvatore Furnari, Researcher at the University of Rome Tor Vergata, Member of the research team led by Professor Raphael Lehner. In his speech, Salvatore Furnari discussed the flaws of the algorithm in the robo-advisor and compensation for investors. He noted that, despite the various concerns about the use of artificial intelligence technology, we should not only ask ourselves whether we should develop these technologies or not, but we should also ask ourselves how to manage and guide them, building this approach upon shared values and principles. Among the risks posed by artificial intelligence and robotics, the most significant challenges noted by the speaker are: 1) opacity; 2) autonomy; 3) combination of technologies. 
It is necessary to assess to what extent the legislation is adequate to address these problems. During his speech, he gave special attention to the concept of defective goods and the manufacturers' liability for them in accordance with the EU Directives.

In the first part of the plenary session, Yulia V. Kharitonova, Professor of the Department of Entrepreneurial Law of the Law Faculty of Lomonosov Moscow State University, Dr. Sci. (Law), presented the topic of "Citizens' Rights in the Digital Environment: Basic Paradigms of Regulation in Russia, China and the EU" in a multidimensional scope. She dwelled on the rights of citizens related to the development of digital technologies and noted that Europe, Asia and Russia are moving in the same direction on this issue.

Then the floor was given to Dmitry V. Lomakin, Dr. Sci. (Law), Professor of the Civil Law Department of the Faculty of Law of Lomonosov Moscow State University. In his speech, he drew attention to the fact that there are corporate rights, the effect of which, regardless of who they belong to, can only be for individuals. Such rights include the right to information, and in his speech he scrutinized the essence and procedure for their implementation in limited liability companies. The speaker raised a question of abuse of the right to information and noted that the right to information is valuable in not only itself, but also serves as a guarantee for the exercise of other corporate rights in a business society.

Wang Zhi Hua, Doctor of Law, Professor of China University of Political Science and Law, Deputy Chairman of the Russian Law Research Center at China University of Political Science and Law, Deputy Chairman and General Secretary of the Association of Comparative Law of China, made a report. Professor noted that in the Chinese legislative system, there are only three main laws that provide civil liability. They are the General Provisions of the Civil Law (1986), the Tort Liability Law (2009) and the Civil Code of the People's Republic of China, effective January 1, 2021. With the entry into force of the Civil Code of the People's Republic of China, the other two laws lost their legal force. In his speech, he elaborated on the types of civil liability, the grounds and forms of civil liability. 
A very interesting topic was presented by Vera L. Izhevskaya, MD, Deputy Director for Scientific Work of the Bochkov Research Center of Medical Genetics. She delivered her speech on "Ethical Problems of Prenatal Genetic Testing" where she drew attention to the need to define the ethical principles that should be the basis of the law, and to determine the limits of interference in a person. She noted that the ethical problems of prenatal genetic testing are associated with deep differences of opinion in society regarding the anthropological and moral status of human embryos and revealed the existing approaches.

During the plenary session, other interesting reports were also delivered, in particular, by Svetlana A. Karelina, Dr. Sci. (Law), Professor of the Department of Business Law of Lomonosov Moscow State University; Yaroslav Turlukovskiy, Dr. Sci. (Law), Lecturer of the Department of Commercial Law at the Faculty of Law and Administration of the University of Warsaw, Director of the Center for Studies of Law in Eastern Europe and Central Asia, Faculty of Law and Administration of the University of Warsaw; Sergey A. Sinitsyn, Acting Deputy Director of the Institute of Legislation and Comparative Law under the Government of the Russian Federation, Dr. Sci. (Law); Elena A. Abrosimova, Dr. Sci. (Law), Associate Professor, Head of the Department of Commercial Law and Fundamentals of Law at the Faculty of Law of Lomonosov Moscow State University; Irina A. Emelkina, Dr. Sci. (Law), Professor of the Faculty of Law of the HSE University; Vadim E. Mantrov, Dr. Sci. (Law), Associate Professor of the Faculty of Law of the University of Latvia; Marina L. Nokhrina, Cand. Sci. (Law), Associate Professor of the Notary Department of the Faculty of Law of St. Petersburg State University; Varvara V. Bogdan, Dr. Sci. (Law), Associate Professor of Southwestern State University; Olga M. Rodionova, Dr. Sci. (Law), Professor of the Department of Civil Law of Kutafin Moscow State Law University; Yuliana A. Kitsai, Cand. Sci. (Law), Associate Professor of the Department of Civil Law and Procedure of Immanuel Kant Baltic Federal University; Sun Qi, Research Assistant of the Shanghai Academy and other jurists.

Within the framework of the Congress, with the financial support of the RFBR, under the scientific project No 18-29-16060 "The Impact of Digital Technologies on Civil and Administrative Justice”, a panel 
discussion on "The Role of Human and the Role of IT in Judicial Protection" was organized. Elena G. Streltsova, Cand. Sci. (Law), Associate Professor, Associate Professor of the Department of Civil and Administrative Justice of Kutafin Moscow State Law University (MSAL) moderated this discussion.

On December 5, 2020, within the framework of the Congress MSAL also hosted such events as master classes for young scholars, presentations given by young graduate students, and creative workshops for students moderated by leading experts and scholars. The creative workshops were sponsored by the Consultant Plus company. Participants of the creative workshop on intellectual property received gifts from the World Intellectual Property Organization.

During the congress all registered participants were given an opportunity to view a recording of the ballet "The Nutcracker" staged by the world ballet star, a MSAL graduate Nikolay Tsiskaridze, and performed by the artists of the troupe of Natalya Sats Moscow State Academic Children's Musical Theater. The Organizing Committee of the Congress thanks the management of the theater for the opportunity to post a video of the ballet for viewing by the participants of the Congress.

\section{Information about the Author}

Elena A. Morgunova, Cand. Sci. (Law), Associate Professor, Deputy Head of the Department of Civil Law, Kutafin Moscow State Law University (MSAL); Deputy Chairperson of the Organizing Committee of the Congress, Moscow, Russia

9 Sadovaya-Kudrinskaya ulitsa, Moscow 125993, Russia eamorgunova@msal.ru 